\title{
Cancer immunotherapy: recent advances and challenges
}

Since the 1890s, attempts have been made to harness the immune system to treat cancer (1). However, only over the last decade have we witnessed the true potential of immunotherapy. Activating the immune system by removing negative regulators has shown benefit in many cancers and continues to shape our understanding of the immune response to cancer. This tremendous success has led to the establishment of immunotherapy as one of the main pillars of cancer treatment. Immune checkpoint inhibitors (ICI) are the poster child of this success with more than 50 Food and Drug Administration approvals for the treatment of various cancers (2).

The immune-oncology landscape is rapidly evolving and currently spans T-cell targeted agents, cell therapies, cancer vaccines, oncolytic viruses, CD3-targeted bispecific antibodies, and various other immunomodulators. A recent report, in 2020, showed that approximately 4,720 immuno-oncology drugs were in the developmental pipeline, and around 6,281 clinical trials were actively investigating these agents (3). There are still several challenges with these agents. At present we lack robust predictive biomarkers and have sparse knowledge of the mechanisms of primary and secondary resistance and the causality of immune-related adverse events. A deeper understanding of these roadblocks will help us with the development of a more personalized treatment approach which will be not only more effective but also much better tolerated.

In this focused series, we celebrate the success of these agents and provide a comprehensive overview of challenges with cancer immunotherapy. Discussed topics include immune-related adverse events and financial toxicities, safety concerns in patients with pre-existing immune dysfunction, current and emerging biomarkers of response along with a detailed discussion on the role of the gut microbiome in modulating response to ICI. Other reviewed topics include chimeric antigen receptor T-cell (CAR T-cell) therapy and ICI in lymphoid malignancies, clinical studies exploring ways to turn immunologically inert "cold" sarcomas "hot" and intralesional agents in the treatment of malignant melanoma.

\section{Acknowledgments}

We would like to thank Teresa Lin for her great effort and support during the preparation and completion of this series. Funding: None.

\section{Footnote}

Provenance and Peer Review: This article was commissioned by the editorial office, Annals of Translational Medicine for the series "Cancer Immunotherapy: Recent Advances and Challenges". The article did not undergo external peer review.

Conflicts of Interest: Both authors have completed the ICMJE uniform disclosure form (available at http://dx.doi.org/10.21037/ atm-21-2325). The series "Cancer Immunotherapy: Recent Advances and Challenges" was commissioned by the editorial office without any funding or sponsorship. US and MM served as the unpaid Guest Editors of the series. US serves as an unpaid editorial board member of Annals of Translational Medicine from May 2019 to Apr 2021. US reports consultancy/ advisory for Seattle Genetics. MM reports consultancy/advisory board for Blueprints Medicine, Immunocore, Amgen, Trieza, Array Biopharma, Biontech and Novartis. He also currently serves on Exicure Executive Steering Committee. The authors have no other conflicts of interest to declare.

Ethical Statement: The authors are accountable for all aspects of the work in ensuring that questions related to the accuracy or integrity of any part of the work are appropriately investigated and resolved.

Open Access Statement: This is an Open Access article distributed in accordance with the Creative Commons AttributionNonCommercial-NoDerivs 4.0 International License (CC BY-NC-ND 4.0), which permits the non-commercial replication and distribution of the article with the strict proviso that no changes or edits are made and the original work is properly cited (including 
links to both the formal publication through the relevant DOI and the license). See: https://creativecommons.org/licenses/by-nc$\mathrm{nd} / 4.0 /$.

\section{References}

1. Coley WB. The treatment of malignant tumors by repeated inoculations of erysipelas. With a report of ten original cases. 1893. Clin Orthop Relat Res 1991;(262):3-11.

2. Sharma P, Siddiqui BA, Anandhan S, et al. The next decade of immune checkpoint therapy. Cancer Discov 2021;11:838-57.

3. Upadhaya S, Hubbard-Lucey VM, Yu JX. Immuno-oncology drug development forges on despite COVID-19. Nat Rev Drug Discov 2020;19:751-2.

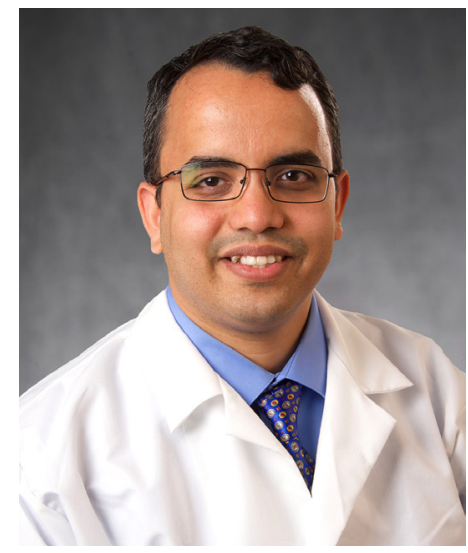

Umang Swami

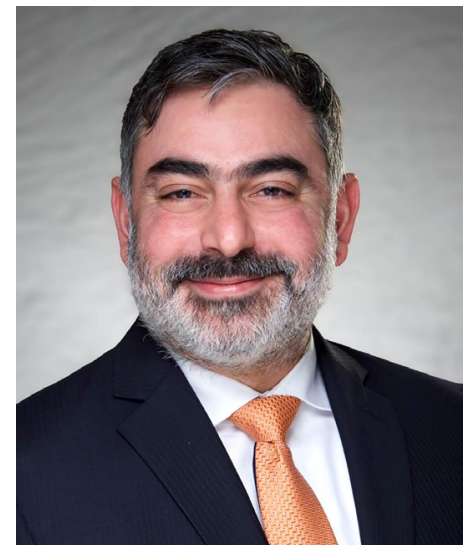

Mohammed Milhem

Umang Swami, MD, MS^ Assistant Professor, Division of Medical Oncology, Department of Internal Medicine, Huntsman Cancer Institute, University of Utah, Salt Lake City, UT, USA.

(Email: umang.swami@hci.utah.edu)

Mohammed Milhem, MBBS

Clinical Professor, Department of Internal Medicine, Division of Hematology, Oncology, and Blood and Marrow Transplantation, University of Iowa, Iowa City, IA, USA.

(Email:mobammed-milhem@uiowa.edu)

Submitted May 06, 2021. Accepted for publication May 14, 2021.

doi: 10.21037/atm-21-2325

View this article at: http://dx.doi.org/10.21037/atm-21-2325

Cite this article as: Swami U, Milhem M. Cancer immunotherapy: recent advances and challenges. Ann Transl Med 2021;9(12):1032. doi: 10.21037/atm-21-2325

\footnotetext{
$\wedge$ ORCID: 0000-0003-3518-0411.
} 